\title{
EMPLOYMENT RELATIONSHIPS AND MEANING OF WORK: A RESEARCH WITH HIGHER EDUCATION PROFESSORS
}

\author{
HÉLIO ARTHUR R. IRIGARAY ${ }^{1}$ \\ (iD) https://orcid.org/0000-0001-9580-7859 \\ LUCIA B. OLIVEIRA ${ }^{1}$ \\ (iD) https://orcid.org/0000-0001-7792-5552 \\ ELAINE S. T. BARBOSA ${ }^{1}$ \\ (iD) https://orcid.org/0000-0001-6352-2824 \\ ESTELLE M. MORIN ${ }^{2}$ \\ (iD) https://orcid.org/0000-0003-3930-8208
}

To cite this paper: Irigaray, H. A. R., Oliveira, L. B., Barbosa, E. S. T., \& Morin, E. M. (2019). Employment relationships and meaning of work: A research with higher education professors. Revista de Administração Mackenzie, 20(1). doi:10.1590/1678-6971/eRAMG190070

Submission: Abr. 29, 2018. Acceptance: July 16, 2018.

\footnotetext{
1 Fundação Getulio Vargas (FGV), Rio de Janeiro, RJ, Brazil.

2 HEC Montreal, Montreal, Quebec, Canada.
}

\section{(cc) BY




\section{ABSTRACT}

Purpose: To explore the meaning of work, analyzing and comparing how it is experienced by workers who are subject to different employment relationships.

Originality/value: The research is important because it advances in the discussion about the flexibilization of labor relations and its impact on how professionals experience and attribute meaning to their work. In addition, we found a gap in empirical research relating to the meaning of work and different types of employment relationships.

Design/methodology/approach: We conducted qualitative and exploratory research with professors from the same higher education institution that work under different employment relationships. Forty-five professors participated in the study, whose reports were submitted to discourse analysis.

Findings: Initially, the results reinforced the six categories proposed by Morin (2001): work that 1. generates results; 2. is intrinsically satisfactory; 3 . morally acceptable; 4 . source of satisfactory relationships; 5 . guarantees security and autonomy, and 6 . keeps the person occupied. In addition, three new categories associated with the professors' work have been identified: "work as a calling", "work as identity construction", and "work as a masochistic practice". Our results point to the complexity of maintaining professionals working side by side but under different employment relationships. Resentment, anguish, and frustration were some of the feelings that we consider to be associated with this reality, and represent a challenge to be faced by organizations.

\section{KEYWORDS}

Meaning of work. Employment relationships. Nonstandard work arrangements. Professor. Higher education. 


\section{INTRODUCTION}

The existence of multiple employment relationships is a reality of the contemporary workplace, and it includes part-time and temporary work, as well as informal arrangements, in which the worker does not have access to benefits and legal guarantees (Azevedo \& Tonelli, 2014; Azevedo, Tonelli, \& Silva, 2015; Kalleberg, 2000). In Brazil, such an informal arrangement is known as PJ (Pessoa Jurídica [Legal Person]), in which the worker constitutes a company and provides services to the organization (Azevedo \& Tonelli, 2014; Campos, 2016).

The flexibilization of work relationships, however, has not eliminated the importance of work for people and society. Many researchers have studied the meaning of work, trying to understand the ways in which employees give and attribute meaning to their work, as well as possible shifts that may be occurring (Morin, 2001; Rosso, Dekas, \& Wrzesniewski, 2010; Quintanilla \& Wilpert, 1991).

The teaching career, once seen as secure and of high social status, has also been affected by flexibilization policies and practices (Paiva \& Saraiva, 2005; Vilas Boas \& Morin, 2014). Additionally, research professors, whose work involves a combination of teaching, research, and extension, have been affected by academic productivism, which requires an increasing amount of dedication and effort, and may promote excessive competition, with potential impacts on their health and well-being (Nascimento \& Salvá, 2013; Paiva \& Saraiva, 2005; Vilas Boas \& Morin, 2014). Given this reality, the following question instigated the present study: How is the meaning of work experienced by higher education professors who are subject to different employment relationships?

To answer it, we conducted an empirical study in a private Higher Education Institution (HEI) headquartered in Rio de Janeiro, in which the professors work under three different employment contracts: 1 . formally employed faculty, members of the permanent board of professors who work as researchers and teach undergraduate and graduate courses, including masters and doctoral programs (career professors); 2. professors who are also formally employed, but teach only undergraduate and professional masters courses, and do not belong to the permanent board of professors (extra-career professors); 3. professors with no formal employment relationship with the organization, who work in MBA courses (invited professors). 
The relevance of this study lies in the value attributed to work in our society, and therefore in the importance of understanding how it is experienced, especially considering its flexibilization and casualization. Additionally, we did not find other national studies focused on understanding how the meaning of work is articulated in the presence of multiple employment relationships within the same organization. The focus on higher education professors also contributes to the study's relevance, given evidence suggesting that this professional group has been affected both by a wider world of work transformations as well as changes in the nature of the teaching profession (Nascimento \& Salvá, 2013; Passos \& Freitas, 2015). Finally, there is also a dearth of research on the meaning of work conducted in Brazil (Paiva \& Saraiva, 2005; Spinelli-de-Sá \& Lemos, 2015; Tolfo \& Piccinini, 2007).

From an applied perspective, understanding the meaning of work for higher education professors may contribute to the development of managerial policies and practices that foster their motivation, satisfaction, and productivity - with positive impacts on all stakeholders of HEI.

\section{THEORETICAL FRAMEWORK}

\subsection{Employment Relationships}

Over the last decades, employment relationships have changed significantly across the entire world. The traditional job model-characterized by formal and full-time contract of indefinite duration - has lost ground to more flexible relationships, such as temporary jobs and part-time or fixedterm employment (Cappelli, 1999; Kalleberg, 2000).

In Brazil, after the 1990s trade opening, local companies were faced with the need to reduce costs and improve their competitiveness. The Brazilian labor market was also affected by downsizing efforts and the adoption of more flexible work arrangements (Piccinini, Oliveira, \& Rübenich, 2006). Workers who were once full-time employees became self-employed, outsourced, associated with colleagues in cooperatives, constituted legal entities, among other alternatives (Azevedo \& Tonelli, 2014; Campos, 2016; Kim, Tonelli, \& Silva, 2017). Besides that, informal labor, with no legal guarantees, has always been a part of our reality and accounts for a significant amount of jobs (Noronha, 2003). Therefore, labor relations became more complex and the workforce, more heterogeneous - with diversified and uncertain employment contracts (Antunes, 2009). 
Azevedo and Tonelli (2014) studied the different employment contracts of qualified employees and their results showed that, because of this diversity, such relationships cannot be treated homogeneously. According to the authors, both organizations and workers are unprepared to deal with such disparities. In another study with executives who migrated from formal to flexible work arrangements, Kim et al. (2017) identified that the notion of a "real job" is associated with a formal employment contract, protected by the labor law (CLT).

In this study, the career and extra-career professors are formally employed by the HEI and have their rights defined by law, which includes a monthly fixed salary, annual paid vacation, Christmas bonus salary, undetermined contract duration, and full-time work regime. Career professors make up the permanent board of the masters and doctoral programs and, therefore, enjoy higher status and prestige. They are exclusively dedicated to the HEI. The extra-career professors work as lecturers in undergraduate and professional masters courses and may have work relationships with other HEIs. The invited teachers are not formally employed and work as legal entities (PJ). According to Dedecca (2009), this last type of relationship is a form of socially unsafe employment contract quite common in some segments of the market and professional profiles.

\subsection{The meaning of work: What is being a professor?}

Work and its meanings have been studied under various ontological and epistemological points of view (Morin, Tonelli, \& Pliopas, 2007; Rohm \& Lopes, 2015; Rosso et al., 2010). Various definitions can be found for the meaning of work, some more limited, which associate work with paid activity, and others more open (Drenth, 1991). Despite multiple interpretations and understandings, work is considered to have a positive side, associated with the achievement or production of something, and a negative side, as it involves effort and some degree of obligation or necessity (Noon \& Blyton, 2007; Rodrigues et al., 2017).

In a literature review on the senses and meanings of work, Tolfo and Piccinini (2007) a distinction between both terms is proposed, highlighting that meaning would be related to an objective social dimension, while sense would involve individual or subjective aspects. On the other hand, the authors point out that the terms may be treated as synonyms, considering the construct's multidimensionality and the word's etymology. For this study, in line with other Brazilian researchers, we opted for the synonymic approach (Bispo, Dourado, \& Amorim, 2013; Neves et al., 2018). 
Tolfo and Piccinini (2007) also identified that this subject has been underexplored in Brazil, with studies are predominantly based on frameworks proposed by the Meaning of Working International Research Team (1987) and Morin (2001).

In this study, we opted to work with the model proposed by Morin (2001), who suggests the existence of six characteristics or aspects that give meaning to work: 1 . being efficiently executed, leading to positive results; 2. being intrinsically satisfactory or, in other words, enjoyable; 3 . permitting the construction of satisfactory relationships, both within and outside the organization; 4 . being morally acceptable, which includes contributing to society; 5 . guaranteeing the employee's financial stability and independence; 6. keeping the employee busy, making him/her feel useful and giving meaning to everyday life.

On the meaning of work for higher education professors, there seems to be a tension between pleasure and suffering, with the enjoyment coming from human contact, the act of teaching, financial independence, and schedule flexibility. The suffering, on the other hand, would arise from work relationship issues, bureaucratic activities, and the perception that work is ubiquitous, being always on the professor's mind, pressuring him/her (Menezes, Nepomuceno, \& Batista-dos-Santos, 2011).

Teachers who travel constantly have also been studied (Passos \& Freitas, 2015). Results showed that work is central to their lives and pleasurable, as far as they are able to form and transform lives. The relationship with students and the possibility/responsibility of being role models is also perceived as positive. However, the issue of ubiquity (Menezes et al., 2011) has also been identified and, according to the authors, is intensified in the case of mobile teachers, since frequent travels tend to interfere more on their personal lives.

More recently, Medeiros and Teixeira (2017) analyzed managerial practices of private and public universities and their impacts on professors. Results showed that respect and autonomy are more present in public universities than in private ones. On the other hand, the political games of the public universities tend to partly jeopardize professors' autonomy and freedom of action.

In short, studies with Brazilian professors suggest that work is predominantly perceived as central and as a source of pleasure and personal fulfillment. On the other hand, these workers also face many personal and professional challenges. 


\section{METHODOLOGICAL PROCEDURE}

The present study was guided by the ontological premise that there are multiple voices and realities, and by the assumption that understanding the meanings of social actions should be based on the perspective of the subjects, not of the researchers (Gergen, 1991). Therefore, we opted for a qualitative exploratory study.

Data were collected through personal interviews and participant observation. The semi-structured interviews were based on a three-part script. The first part covered participants' professional trajectory. The second had questions on career choice motivations, as well as the profession's negative and positive aspects, including the relationship with the HEI. The third part focused on the meaning of work as a professor. Participant observation was done by one of the study's authors - who works in the HEI - during approximately six months, coinciding with the period in which the personal interviews took place. During this period, informal conversations and observations were registered in a field diary, allowing a better understanding of the participants' professional experiences.

To all participants, it was granted anonymity and confidentiality of their reports, which were transcribed and analyzed through discourse analysis, a technique considered appropriate to the study objectives. As Orlandi (2003, p.15) highlights, "in discourse analysis, one attempts to understand language as it gives a sense, as a symbolic work, as part of general social work, constituting man and his history".

The study involved 45 professors, being 29 invited professors, 13 career professors, and three extra-career professors, a smaller group in the HEI under study. The invited professors were 23 men and six women, with ages between 36 and 68 years old. Regarding their academic background, there were 17 masters, seven doctors, and five specialists. The career professors were elevan men and two women, with ages between 28 and 74 years old. Twelve were doctors and one had a master's degree. Finally, of the extracareer professors, there were two men and one woman, with ages between 34 and 44 years.

\section{FINDINGS}

We identified that the meaning of work for the professors of all three groups followed the six categories proposed by Morin (2001): work that 
generates results, keeps the person occupied, guarantees security and autonomy, is intrinsically satisfactory, morally acceptable, and a source of satisfactory relationships. However, besides these a priori defined categories, three new categories emerged from the data, which were named "work as a calling", "work as identity construction", and "work as a masochist practice". All of them are discussed next.

\subsection{Work that creates value}

The first category, proposed by Morin (2001), indicates that meaningful work involves some type of accomplishment, as also noted by Noon and Blyton (2007). In our study, we observed that, regardless of the employment relationship, teaching makes sense when it is not limited to the transmission of technical knowledge, but especially when teacher-student interaction contributes to the pupils' development. Some professors highlighted their role in student's counseling and support, evidencing the profession's humanized side. Therefore, being a professor means, for all studied groups, adding value to the students, in the form of knowledge and skills that they may directly apply in their work and their lives.

The professor's job is to add value. It's very important to add value to someone, to contribute somehow to someone. (Career professor)

A teacher's gratification is not the feeling of continuing a student's education [...], it is seeing that he/she applies this new knowledge and achieves a result. That is, to me, a gratifying moment. Epiphany is when that happens. (Career Professor)

The word "epiphany" refers to a sensation of profound realization, of considering something solved, cleared up, or complete. From this perspective, realization as a professor does not come from teaching itself, but from students' practical application of knowledge, contributing to their personal and professional growth. This result is in line with other studies with Brazilian higher education professors, evidencing that working as a teacher has meaning as long as it "makes a difference" in the students' lives (Menezes et al., 2011; Passos \& Freitas, 2015).

However, it is worth noting that our study indicated that, among career professors, especially younger ones, research activities may be assuming a dominant role, making teaching a secondary activity. In this sense, the contribution to students tends to occur predominantly when they are perceived as research partners. 


\subsection{Intrinsically satisfying work}

In this category, work acquires meaning as it is intrinsically satisfying, resulting in a pleasant and rewarding feeling with work itself (Morin, 2001). The three professional groups perceive their work as intrinsically satisfying, but the source of that satisfaction was shown to be quite different.

For career professors, satisfaction is directly associated with obtaining research funding, participating in congresses and conferences, and fundamentally, publishing articles in high impact journals. Strictly speaking, these professors identify themselves more as researchers than lecturers, as indicated in the previous section.

For invited professors, for whom teaching is their main activity in the HEI, it was clear that being in the classroom is what gives them the greatest pleasure, especially when students are highly involved and willing to participate.

Have you heard about concept of flow? Its ecstasy, it is when you give your best. I feel myself in that state when I am in a classroom where students are participative. [...] I feel pleasure in the classroom (Invited professor)

I am realized when in a classroom, it is my stage. It is like my place in the world. (Invited professor)

The lexical selections "ecstasy" and "center of attention" indicate that the invited professor's satisfaction may be linked to egocentrism, given that both may be related, respectively, to personal pleasure and vanity. Furthermore, this same vanity is present when we note that these professors value their relationship - despite being informal - with a high prestige HEI, given that it confers them social status.

Besides the intrinsic satisfaction from the work activities, invited professors highlighted autonomy - especially the freedom to choose the content and teaching methods in the classroom, and not having to respond to a boss -, challenge, and the absence of routine, even when teaching the same subjects.

The good thing about a professor's job is that you have no boss, no one tells you how to do it. (Invited professor)

It's always different, even if you give the same class, it's always a new experience, the class is the same, but each one is a different experience. Tiring, but good. (Invited professor) 
A teacher's job is a constant challenge, but it's fun. I like doing everything I do, meeting goals, I keep imposing new limits on myself. (Invited professor)

Finally, the extra-career professors seem to be between invited professors and career professors, since they value teaching, which occupies an important part of their time, as much as their research activities, perceived as necessary to obtain a position of higher academic prestige, either in the HEI or elsewhere.

\subsection{Morally acceptable work}

In this category, Morin (2001) defines work as one that contributes to society and that, thus, transcends personal interests. For interviewees from all groups, a professor's work is perceived as one that mostly contributes towards this goal. Some participants report that, as teachers, they have not only the opportunity but also the responsibility to form better human beings.

Work is the opportunity we have to transform our knowledge into reality, to contribute to the development of a society and of a nation. (Invited professor)

Besides developing society, a teacher has the opportunity to leave a legacy, [... ] to benefit a greater group of people. (Extra-career professor)

In short, work makes sense to professors when, through their teaching activities, they can contribute to society and to their students individually, transcending personal interests, such as ego satisfaction and money.

Regarding this category, we identified a problem involving high competition and excessive expectations both among career professors, evaluated by "Capes points", and invited professors, who must please those responsible for teaching allocations: "If you're being successful, you're fine". Our analysis suggests that this reality may be affecting this source of meaning, as the professors' priority stops being the students' formation and becomes their own "survival".

On the other hand, we also identified that teaching is perceived as a calling to some professors, suggesting the existence of another category that places work beyond being morally acceptable (Morin, 2001), as discussed next. 


\subsection{Work as a calling}

Some professors, both invited and career, especially older ones, associated teaching to "priesthood" or a "vocation".

I feel obliged to pass on my knowledge. I wound up discovering that it was my vocation. People say that I was made for this profession. (Invited professor)

In the literature on calling, there are three conceptualizations for the term, known as classic, modern, and neoclassic (Xie, Xia, Xin, \& Zhou, 2016). The classic is associated with a calling from God, and seen as excessively strict, as it presupposes the existence of religious beliefs. The modern perspective, on the other hand, is regarded as too broad, since it considers as a calling satisfaction professional life and career choices (Xie et al., 2016). Therefore, the neoclassic approach is considered more appropriate, as calling is defined as a transcendent summoning for the fulfillment of a life role, which is related to a sense of purpose and oriented towards others (Dik \& Duffy, 2009; Xie et al., 2016). To Wrzesniewski, McCauley, Rozin, and Schwartz (1997), individuals who see their work as a calling perceive it to be an inseparable part of their lives, something that they are "called" to do, as present in the following statements.

You need a purpose. I often give free lectures and training, because the intention is to help people. If I reach even one person, I'm happy. So, meaningless work is when I can't reach people. (Invited professor)

Everything I do is to illuminate my role as a teacher. That is the meaning of everything. (Career professor)

Thus, we understand that a model that seeks to explain the meaning of work, in all its richness and diversity, needs to incorporate this facet of work, related to a sense of purpose and altruism. Another category that emerged from the data relates the meaning of work to identity construction, as discussed next.

\subsection{Work as identity construction}

This category emerged from reports about the relationship between interviewees and the HEI, suggesting that the type of employment 
relationship is a constitutive element of the meaning of work, through a process of identity construction.

For career professors, formally employed by the HEI, we observed the existence of two distinct subgroups, defined by age and organizational tenure. Older professors who have also been working longer for the HEI revealed a strong attachment to the institution, to the point of saying that they are "proud to have built it". Their identity is also defined as "a professor", described as an agent of social change and student formation.

My profession allows me to change the world for the better.

(Career professor)

A good teacher is eternal, changes the students' lives forever.

(Career professor)

The younger career professors, on the other hand, seem to be more attached to their own accomplishments and their identity as researchers, pointing to the new career models discussed in the literature, in which workers are committed to their personal development, instead of the employer (Sullivan \& Baruch, 2009). Their identity as professors and the attachment to the HEI are, therefore, secondary.

The extra-career professors recognize their identity in the teaching profession, but also highlight the importance of being attached to the HEI.

Not being a full-time professor isn't the best, but at least I work for a prestigious institution, and that impresses people. (Extra-career professor)

The lexical selections "prestige" and "impresses people" suggest the social value of working for a prestigious institution, which generates recognition and identity among extra-career professors. Such value is also revealed in their aspiration of becoming a member of the permanent board.

This identity construction process was also present in the interviews with invited professors, who claim that being a professor of this institution is a source of pride and a synonym of power and reference. At the same time, this identity is described as ephemeral and transitory, since they feel that they can be discarded at any moment.

I'm admired in my day to day life, my children are proud, my friends are proud. It makes me feel good, having this recognition from close people. Being a teacher in this institution opens doors. (Invited professor) 
I'm a luxury accessory, especially in a suit and tie. And I think it's fun, I don't think I'm essential, I'm a commodity, they could easily replace me. (Invited professor)

In short, for practically all participants - except young, short-tenure career professors - their identity is constructed from their belonging to the institution. The importance of presenting themselves and being recognized as "HEI professors" has appeared frequently in their reports. Curiously, this value seems to be more intense among invited professors, who see the institution as a source of status and income, but at the same time resent the lack of a formal contract with it.

\subsection{Work as a source of satisfactory relationships}

In this category, Morin (2001) highlights the importance of social relationships at work. For all participants, these occur with peers and students, but in an ambiguous manner.

For career professors, relationships with peers did not emerge in the interviews, therefore suggesting that they were not relevant. The interactions with students, on the other hand, were highlighted and included both, those that occur in the classroom as well as in advisory activities. The students, namely from masters and doctoral programs, were perceived as competent apprentices involved in research projects. The benefits of being with younger people were also emphasized. These relationships, therefore, seem to represent a fruitful arena for academic development and professional selfrealization.

A teacher's job is to rejuvenate, to renovate. It's being a part the world. It's essential. (Career professor)

My room is always open to students, I think I have a good relationship with them and that makes me want to do cutting-edge things, to do good research. The interaction with students is a challenge for you to always be on the frontier, always evolving. (Career professor)

The extra-career professors highlighted their close relationships with undergraduate students and peers, which results in a pleasant working environment, recognized in the interviews as a constitutive element of the meaning of work. 
Being a teacher is being a model, where the students can mirror themselves and count on. I highly value the exchange with the students. (Extra-career professor)

Finally, the invited professors reported having ambiguous, conflicting, and occasionally antagonistic relationships with students and peers. Regarding peers, some professors claim that colleagues are their family when they are traveling, those "you count on when something bad happens". On the other hand, there was also evidence of competition with peers, sometimes hidden, regarding both class schedules and students' evaluations. Analogously, the relationship with students is frequently described as a source of pleasure and realization, but some professors reported some resentment with students perceived as lenient, academically weak, or even threatening since they can affect the professor with negative evaluations. Furthermore, students are often described as "clients". In this sense, as opposed to career and extra-career professors, who emphasize a masterpupil relationship, for invited professors there seems to exist a commercial relationship, which tends to end along with the course.

What's bad is students and classes that are complicated [...]. The relationship of the professor with the student is very close and the attrition is greater. It doesn't happen all the time, but sometimes it does. (Invited professor)

These results made us question some aspects of this category as proposed by Morin (2011). It may be necessary a clearer definition of what exactly satisfying relationships are, as well as in what manners they give meaning to professors' work. What we observed, especially in the case of invited professors, is that relationships with peers and students can be both satisfying and antagonistic. Considering that competitiveness has been the main characteristic of contemporary organizations, it is possible that this category is going through a metamorphosis.

\subsection{Work that guarantees security and autonomy}

In this category, Morin (2001) relates work to remuneration, which in turn brings a feeling of security and allows some autonomy and financial independence. In the case of career professors, this feeling is the direct result of their research and high impact publications: "What guarantees our 
employability is the quantity of A1 articles we publish". These professors seldom mentioned their salary but emphasized the importance of the financial support provided by the HEI for their research, as well as participation in congresses and conferences.

For extra-career professors, the lack of stability was an issue. Some pointed out that, to keep their job, they must be well evaluated by the students. The search for security appeared in their expectation of being hired as career professors. In fact, one professor declared that:

I like what I do, and I do it because I know that one day I may become a career professor. It would be a complete realization, my life's project. [...] This promise is more important than my salary, it gives me the certainty that I am on the right path. (Extra-career professor)

The lexical selection "promise" suggests a possible shift in this category proposed by Morin (2001). More than a real and current feeling of security, autonomy, and financial independence, there is a possibility that a future perspective of such safety may also be connected to the meaning of work.

The invited professors highlighted the compensation they receive for their teaching activities, which, for some, is their main source of income and, for others, is a complement to other paid activities. For many of them, the work as a professor - which frequently involves long trips and an intense teaching load, with consequent physical and emotional strain - makes sense, fundamentally, for the money they receive.

Obviously, I think we should earn more, but where else would we earn [...] in a weekend? Not even counting the miles [...]. Thanks to this job, I already bought an apartment and I can travel abroad with my family every year. (Invited professor)

On the other hand, insecurity also appears in these participants reports, because of their informal relationship with the HEI.

We're legal persons. Today we're booked, tomorrow we might not be. This makes us think about how much all of this is worth. (Invited professor)

Morin (2011) gathered in a single category, security, autonomy, and independence, which, in our understanding, only makes sense when workers 
are under formal relationships. When it does not happen, as in the case of invited professors, there is a noticeable feeling of insecurity and anxiety. The instability that comes from informal relationships jeopardizes not only one's sense of belonging but also their relationship with work itself. In fact, questioning the worth of one's dedication to the demands of teaching has appeared in the reports of many professors from this group.

\subsection{Work that keeps one occupied}

In this category, Morin (2001) points to the importance of work as an occupation and as a way of structuring time. This mechanism of meaning was not emphasized during the interviews. When discussing the issue of time, we observed that the participants - particularly career professors seem to value flexibility or the possibility of choosing when to work and when not to, especially regarding research activities.

The good side is schedule flexibility [...]. Being a teacher is the rigid part, and I cannot not give my morning class, I can't miss it, but in my research activities, I have more flexibility. (Career professor)

On the other hand, what was greatly emphasized was the invasion of work in moments that could be dedicated to family and leisure, evidencing that the intensification of work is a reality among the professors that participated in this study. For invited professors, the frequent trips and all the demands associated with teaching takes a toll in terms of time, especially for those who have other paying jobs. Several professors reported conflicts between work and life, with negative effects on their health and family relationships.

The bad side of being a professor is that we are nomads, we have to give up a lot. I'm divorced, many of us are divorced. (Invited professor)

Regarding career professors, they complained not only about the pressure to publish but also about the work involved in teaching.

Being a teacher is an exclusive dedication, you have to prepare and think about classes [...], you have the classes, when you deal with students when you're on the stage. [. . .] And there's grading exams and assignments, which is a lot of work. You have to accompany students in their trajectory. For me, it's full time, because when you're 
at home, on the web, and you remember something for a class, you get up and go write it down. So, that's why I say exclusive dedication. (Career professor)

The expressions "exclusive dedication" and "full time" reveal a sense of ubiquity and all the weight that comes with it. This feeling was also shared by extra-career professors, who find themselves facing a double-demand: publishing like a professor from the permanent board and teaching undergraduate and graduate courses, or even as an invited professor, to complement their income.

In this sense, it is possible that this category that relates work and time may be going through a metamorphosis, becoming not a mechanism of meaning, but a source of suffering. In other words, the idea that meaningful work is one that maintains a person occupied might be losing space. Morin (2001, p. 17) discusses suffering "because of lack of work" and we propose to add that excessive work - both because of the pressure to publish or because of the frequent travels and teaching loads - can also be a source of suffering.

As a counterpoint, it is worth noting that some participants talked about the importance of having an occupation: "I get sad and anxious when I don't have anything to do". Besides that, we observed the teachers' power of agency (Bendassolli, 2011) when reflecting on this matter: "it was the life I chose".

The final category we found was not defined a priori but emerged from the interviews. Named "work as a masochist practice", this category represents the pleasure-suffering dichotomy found in many reports.

\subsection{Work as a masochistic practice: The pain and pleasure of being a professor}

During the interviews, recurring lexical selections used to define the meaning of work as a professor were "spread knowledge", "like to teach", "dedication with patience", "instigate" and "help people". Especially for career professors, the focus on "researching" also appeared, as previously noted.

Besides that, the pleasure of being a professor was associated with success, which is reified by visibility. For career professors, it means earning the best article prize at a conference or having an article published in a prestigious journal. For extra-career professors, visibility occurs when 
publishing an article with a professor from the permanent board and when receiving an invitation to teach a graduate course. For invited professors, visibility is reified by receiving a "professor of the year" award, being completely booked, using a pin with the HEI's name on it, or even, showing off a baggage tag that indicate their status as frequent flyers.

This pleasure, however, comes with the suffering from knowing that the coveted "Qualis points" lasts only four years, which implies an endless effort to publish and remain a member of the permanent board of professors of the masters and doctoral programs. It is physical and psychological suffering. We observed this same anxiety on extra-career professors, who also feel pressure to publish since these "Qualis points" are perceived as indispensable to their promotion to career professor or in obtaining a position in another prestigious graduate program.

For invited professors, the apex of their work as teachers is in the classroom, which they have defined as "my stage", "my place in the world", "the glory". However, they pay the high price of frequent travels, distance from family and friends, as well as the uncertainty of being scheduled for future classes: "until when are we booked?". Among invited professors, this pleasure-suffering dichotomy also emerged from their relationship with the HEI. On one hand, there is the pride from being a part of a prestigious institution, on the other, there is resentment for the lack of a formal contract.

This here [pointing to an HEI pin] means a lot, people respect it, it's a source of pride, despite knowing, in truth, that I'm not part of it, even giving my blood. (Invited professor)

Thus, we propose that the "work as a masochistic practice" dimension be incorporated into the meaning of work models. The concept of masochism, despite traditionally linked to psychoanalysis, has been widened. In our study, we considered the definition proposed by Reik (2013), according to which masochism is "a peculiar attitude towards life", in which the person "unconsciously strive for physical or psychic pain, voluntarily submitting to privations, deliberately accepting sacrifices".

Researchers from various areas of knowledge have studied this subject, including consumer behavior and political science (Kovacevic, 2011; Scott, Cayla, \& Cova, 2017). In an instigating text on the work of university professors in the United Kingdom, Cederström and Hoedemaekers (2012) criticized academic productivism and underscored the apparent paradox of professors who submit themselves to a system that they, in fact, reject. The 
authors conclude that "it would not be outrageous to suggest that the academic game has become masochistic; or more precisely that the game, whatever its wicked nature may be, is one most suitable to the masochist" (Cederström \& Hoedemaekers, 2012, p. 231).

Our analysis showed that the three groups of professors feel pleasure in their work, but at the same time submit themselves to suffering related to their chosen career path. The career professor values his/her work as a researcher and his/her prestigious position but suffers to preserve it, doing work that seems endless. The extra-career professor values his/her job as a teacher and researcher but suffers from the expectation of being recognized. The invited professor feels pleasure in the classroom and is proud to be part of a prestigious HEI, but suffers with constant travels and with the insecurity and resentment of not having a formal contract.

We thus understand that the pleasure-suffering dichotomy or, more specifically, the "masochistic practice" may constitute the meaning of work for higher education professors in contemporary times. They seem to consider that the pleasure from their work must be accompanied by suffering, like a price to be paid. This debate also points to the possibility of discussing concepts from the psychodynamic theory of work (Dejours, 2015) and their connections with multiple employment relationships, which are increasingly prevalent in our society.

\section{FINAL CONSIDERATIONS}

The fragmentation of work and the existence of multiple employment relationships, even within the same organization, is a reality that has motivated us to conduct this study. Our purpose was to analyze and compare the meanings of work experienced by higher education professors that work for the same higher education institution but are subject to different employment contracts. As we related, in the meaning of work with different employment relationships, we could grasp how work values are shifting in the Brazilian society, especially in face of increasing precariousness of employment relationships.

When comparing participants' perceptions, we saw that the type of employment relationship with the HEI was a determinant factor for the meaning they attribute to their work. For career and extra-career professors, who have formal contracts with the HEI, "being a teacher" is associated with a historically prestigious position in society, as someone who holds the 
source of knowledge. For invited professors, on the other hand, the same work is perceived as operational, of little relevance, making them feel easily replaceable, like a commodity.

Based on the model by Morin (2001), we observed that the six proposed categories were relevant to all groups, albeit with some differences among them. The category least mentioned was work that keeps one occupied. On the other hand, problems related to the intensification of work emerged in full force in the reports, especially among career professors, who feel pressured by teaching activities and the need to publish, and among invited professors, subject to an intense routine of trips and classes, as also noted by Passos and Freitas (2015).

In the category of work as a source of significant relationships, the importance attributed to peers and students is worth noting. However, we perceived a shift that seems to be related to the movement towards individualization and increased competitiveness in organizations, even educational institutions. Because of this, it seems that pleasing relationships might be threatened by this competitive and predatory logic.

In the category of work as a source of security and stability, the issue of instability was clearly evidenced, especially among invited professors, a group that has no formal contract with the HEI. This result indicates that Morin's model does not account for this reality, which seems to be increasingly prevalent. Even among extra-career professors, who are formally employed, this security seems problematic, as they wish for a position on the permanent board and have to live only with this promise.

Our study also showed the existence of three new categories - named "work as a calling", "work as identity construction," and "work as a masochistic practice" -, evidencing that the meaning of work may have been shifting in the face of new employment relationships.

The category "work as a calling" shows that, beyond being morally acceptable (Morin, 2001), some professors perceive their work as their vocation, as an activity that involves a sense of higher purpose and altruism. Therefore, the meaning of work could be further analyzed in terms of its social role, as well as the reasons that lead an individual to choose it, a spectrum that seems to range from a calling or priesthood to absolute instrumental rationality (income and non-monetary rewards).

The category "work as identity construction" emerged from the professors' relationships with the HEI, evidencing that part of what defines them as professionals is "being a professor", but also "being a [name of HEI] professor". Moreover, it is also important to note that the career 
professor's identity, especially among the younger ones, seems to be more related to being a researcher than a professor. The pressure surrounding publication in high impact periodicals, which loses its value every four years, seems to be contributing to this result, which may negatively impact these professors' performance in the classroom.

Lastly, the category "work as a masochist practice" showed that the pleasure-suffering dichotomy is increasingly present, as discussed by the psychodynamic theory of work (Dejours, 2015). Additionally, we found evidence that professors may be naturalizing the suffering from their work and spontaneously submitting themselves to privations, in line with the concept of masochism (Reik, 2013).

As a research agenda, we propose a deeper investigation of each new category here identified, aiming for further evidence that could corroborate them. We also suggest research with professional groups submitted to other types of employment relationships, such as in cooperatives, allowing the construction of a meaning of a working model that is wider and more suitable to the current reality of work in our country.

From a practical standpoint, our results point to the great challenge currently faced by organizations that, for different reasons and motivations, chose to have professionals working side by side, but under different employment contracts. Resentment, anguish, and frustration were some of the feelings that we found to be associated with this reality, indicating that organizations need to find ways to enable a more positive and harmonious coexistence, with benefits for all involved - professors, students and the HEI itself. The study may also contribute to professors who identify themselves with one of the studied groups, as it allows a deeper reflection on the meaning of work and promotes their self-knowledge, increasingly necessary in a context of instability and change.

\section{VÍNCULOS PROFISSIONAIS E SENTIDO DO TRABALHO: UMA PESQUISA COM PROFESSORES DO ENSINO SUPERIOR}

\section{$\int$ RESUMO}

Objetivo: Explorar o sentido do trabalho, analisando e comparando como ele é vivenciado por trabalhadores submetidos a diferentes vínculos empregatícios. 
Originalidade/valor: A pesquisa é relevante porque avança na discussão sobre a flexibilização das relações de trabalho e aponta o impacto da flexibilização na forma como profissionais vivenciam o trabalho e atribuem sentido a ele. Ademais, detectamos na literatura uma lacuna em pesquisas empíricas que relacionem sentido do trabalho a diferentes tipos de vínculos empregatícios.

Design/metodologia/abordagem: Conduzimos uma pesquisa qualitativa e exploratória com professores de uma mesma instituição de ensino superior (IES), mas que atuam sob diferentes vínculos de trabalho. Participaram da pesquisa 45 docentes, cujos relatos foram submetidos à análise do discurso.

Resultados: Inicialmente, os resultados reforçaram as seis categorias propostas por Morin (2001): 1. o trabalho que gera resultado, 2. é intrinsecamente satisfatório, 3 . moralmente aceitável, 4 . fonte de relações humanas satisfatórias, 5. garante segurança e autonomia e 6 . mantém a pessoa ocupada. Além disso, também foram identificadas três novas categorias associadas ao trabalho do professor na atualidade: "trabalho como chamado (calling)", "trabalho como fator identitário" e "trabalho como prática masoquista". Nossos resultados apontaram para a complexidade de manter profissionais trabalhando muitas vezes lado a lado, mas submetidos a diferentes vínculos. Ressentimento, angústia e frustração foram alguns dos sentimentos que consideramos estar associados a essa realidade. Por isso, eles representam um desafio a ser enfrentado pelas organizações.

\section{PALAVRAS-CHAVE}

Sentido do trabalho. Vínculos de trabalho. Significado do trabalho. Professor. Ensino superior.

\section{$\int$ REFERENCES}

Antunes, R. (2009). Os sentidos do trabalho: Ensaio sobre a afirmação e negação do trabalho. 2nd ed. São Paulo, SP: Boitempo.

Azevedo, M. C., \& Tonelli, M. J. (2014). Os diferentes contratos de trabalho entre trabalhadores qualificados brasileiros. Revista de Administração Mackenzie, 15(3), 191-220. doi:10.1590/1678-69712014/administracao. v15n3p191-220 
Azevedo, M. C., Tonelli, M. J., \& Silva, A. L. (2015). Contratos flexíveis de trabalho: Diferentes perfis de trabalhadores qualificados brasileiros. RAUSP, 50(3), 277-291. doi:10.5700/rausp1200

Bendassolli, P. F. (2011). Mal-estar no trabalho: Do sofrimento ao poder de agir. Mal-Estar e Subjetividade, XI(1), 65-99.

Bispo, D. A., Dourado, D. C. P., \& Amorim, M. F. C. L. (2013). Possibilidades de dar sentido ao trabalho além do difundido pela lógica do mainstream: Um estudo com indivíduos que atuam no âmbito do movimento hip hop. Revista OES, 20(67), 717-731. doi:10.1215/01642472-2009-025

Campos, A. G. (2016). Impactos da terceirização sobre a remuneração do trabalho no Brasil: Novas evidências para o debate. IPEA: Texto para discussão, n. 2245. Retrieved from http://repositorio.ipea.gov.br/bitstream/11058/7288/1/ td_2245.pdf

Cappelli, P. (1999). The new deal at work. Boston, MA: Harvard University Press.

Cederström, C., \& Hoedemaekers, C. (2012). On dead dogs and unwritten jokes: Life in the university today. Scandinavian Journal of Management, 28(3), 229-233. doi:10.1016/j.scaman.2012.05.007

Dedecca, C. S. (2009). Flexibilidade e regulação de um mercado de trabalho precário: A experiência brasileira. In N. A. Guimarães, H. Hirata, \& K. Sugita (Orgs.). Trabalho flexível: empregos precários? São Paulo, SP: Edusp.

Dik, B. J., \& Duffy, R. D. (2009). Calling and vocation at work: Definitions and prospects for research and practice. The Counseling Psychologist, 37(3), 424-450. doi:10.1177/0011000008316430

Drenth, P. J. D. (1991). Work meanings: Conceptual, semantic and developmental approach. European Work and Organizational Psychologist, $1(2 / 3), 125-133$.

Dejours, C. (2015). A loucura do trabalho: estudo de psicopatologia do trabalho. 6th ed. São Paulo, SP: Cortez.

Gergen, K. J. (1991). The saturated self: Dilemmas of identity in contemporary life. New York, NY: Basic Books.

Kalleberg, A. L. (2000). Nonstandard employment relations: Part-time, temporary and contract work. Annual Review of Sociology, 26, 341-365. doi:10.1146/annurev.soc.26.1.341

Kim, H. N., Tonelli, M. J., \& Silva, A. L. (2017). Do formal ao informal: Executivos que migraram para o trabalho flexível. Revista Brasileira de Gestão de Negócios, 19(63), 133-152. doi:10.7819/rbgn.v0i0.2999 
Kovacevic, F. (2011). Masochism in political behavior: A Lacanian perspective. International Journal of Applied Psychoanalytic Studies, 8(1), 58-73. doi:10. 1002/aps. 277

Medeiros, A. L., \& Teixeira, M. L. M. (2017). Limites da dignidade dos docentes nas práticas de gestão em universidades brasileiras. Revista GUAL, 10(1), 134-154. doi:10.5007/1983-4535.2017v10n2p134

Menezes, L. M., Nepomuceno, L. H., \& Batista-dos-Santos, A. C. (2011). Os sentidos do trabalho para um grupo de professores de uma universidade pública: A dialética prazer-sofrimento em tempos de flexibilidade. Proceedings of the Encontro Anual da ANPAD. Rio de Janeiro, RJ, Brazil, 35.

Morin, E. M. (2001). Os sentidos do trabalho. Revista de Administração de Empresas, 41 (3), 8-19. doi:10.1590/S0034-75902001000300002

Morin, E., Tonelli, M. J., \& Pliopas, A. L. V. (2007). O trabalho e seus sentidos [Special edition]. Psicologia \& Sociedade, 19, 47-56. doi:10.1590/S010271822007000400008

MOW International Research Team. (1987). The meaning of working. London, UK: Academic Press.

Nascimento, R. P., \& Salvá, M. N. R. (2013). A política de avaliação da pós-graduação stricto sensu e o trabalho docente: Rumo ao "produtivismo acadêmico"? Proceedings of the Encontro de Gestão de Pessoas e Relações de Trabalho. Brasília, DF, Brazil, 4.

Neves, D. R., Nascimento, R. P., Felix Jr., M. S., Silva, F. A., \& Andrade, R. O. B. (2018). Sentido e significado do trabalho: Uma análise dos artigos publicados em periódicos associados à Scientific Periodicals Electronic Library. Cadernos EBAPE.BR, 16(2), 1-15. doi:10.1590/1679-395159388

Noon, M., \& Blyton, P. (2007). The realities of work: Experiencing work and employment in contemporary society (3rd ed.). New York, NY: Palgrave.

Noronha, E. G. (2003). Informal, ilegal, injusto: Percepções do mercado de trabalho no Brasil. Revista Brasileira de Ciências Sociais, 18(53), 111-129. doi:10.1590/S0102-69092003000300007

Orlandi, E. P. (2003). Análise do discurso: princípios E procedimentos. Campinas, SP: Pontes.

Paiva, K. C. M., \& Saraiva, L. A. S. (2005). Estresse ocupacional de docentes do ensino superior. RAUSP, 40(2), 145-158.

Passos, J. C., \& Freitas, M. E. (2015). Sobre os sentidos do trabalho para "docentes móveis": Um estudo com professores de Administração. Proceedings of the Encontro de Gestão de Pessoas e Relações de Trabalho. Salvador, BA, Brazil, 5. 
Piccinini, V. C., Oliveira, S. R., \& Rübenich, N. V. (2006). Formal, flexível ou informal? Reflexões sobre o trabalho no Brasil. In V. C. Piccinini, L. Holzmann, I. Kovács, \& V. Naha (Orgs.). O mosaico do trabalho na sociedade contemporânea: Persistências e inovações. Porto Alegre, RS: Editora da UFRGS.

Quintanilla, S. A. R., \& Wilpert, B. (1991). Are work meanings changing? European Work and Organizational Psychologist, 1 (2/3), 91-109.

Reik, T. (2013). Masochism in modern man [Kindle version]. Retrieved from Amazon.com.

Rodrigues, A. L., Barrichello, A., Irigaray, H. A. R., Soares, D. R., \& Morin, E. M. (2017). O trabalho e seus sentidos: Um estudo com peritos criminais da Polícia Federal. Revista de Administração Pública, 51 (6), 1058-1084. doi:10.1590/0034-7612159318

Rohm, R. H. D., \& Lopes, N. F. (2015). O novo sentido do trabalho para o sujeito pós-moderno: Uma abordagem crítica. Cadernos EBAPE.BR, 13(2), 332-345. doi:10.1590/1679-395117179

Rosso, B. D., Dekas, K. H., \& Wrzesniewski, A. (2010). On the meaning of work: A theoretical integration and review. Research in Organizational Behavior, 30, 91-127. doi:10.1016/j.riob.2010.09.001

Scott, R., Cayla, J., \& Cova, B. (2017). Selling pain to the saturated self. Journal of Consumer Research, 44(1), 22-43. doi:10.1093/jcr/ucw071

Spinelli-de-Sá, J. G., \& Lemos, A. H. C. (2015). Sentido do trabalho: Uma análise da produção científica brasileira. Proceedings of the Encontro Anual da ANPAD. Belo Horizonte, MG, Brazil, 39.

Sullivan, S. E., \& Baruch, Y. (2009). Advances in career theory and research: A critical review and agenda for future exploration. Journal of Management, 35(6), 1542-1571. doi:10.1177/0149206309350082

Tolfo, S. R., \& Piccinini, V. (2007). Sentidos e significados do trabalho: Explorando conceitos, variáveis e estudos empíricos brasileiros [Special edition]. Psicologia \& Sociedade, 19, 39-46. doi:10.1590/S0102-71822 007000400007

Vilas Boas, A. A., \& Morin, E. M. (2014). Sentido do trabalho e fatores de qualidade de vida no trabalho para professores de universidades públicas do Brasil e do Canadá. Proceedings of the Encontro Anual da ANPAD, Rio de Janeiro, RJ, Brazil, 38.

Wrzesniewski, A., McCauley, C., Rozin, P., \& Schwartz, B. (1997). Jobs, careers, and callings: People's relations to their work. Journal of Research in Personality, 31 (31), 21-33. doi:10.1006/jrpe.1997.2162 
Xie, B., Xia, M., Xin, X., \& Zhou, W. (2016). Linking calling to work engagement and subjective career success: The perspective of career construction theory. Journal of Vocational Behavior, 94, 70-78. doi:10.1016/j. jvb.2016.02.011

\section{AUTHOR NOTES}

Hélio Arthur R. Irigaray, Escola de Administração de Empresas de São Paulo, Fundação Getúlio Vargas (FGV); Lucia B. Oliveira, Instituto de Pós-Graduação e Pesquisa em Administração (COPPEAD), Universidade Federal do Rio de Janeiro; Elaine S. T. Barbosa, Escola Brasileira de Administração Pública e de Empresas (EBAPE), Fundação Getúlio Vargas (FGV); \& Estelle M. Morin, Department of Psychology, University of Montreal (UdeM).

Hélio Arthur R. Irigaray is now Professor at Escola Brasileira de Administração Pública e de Empresas (EBAPE), Fundação Getúlio Vargas (FGV); Lucia B. Oliveira is now Professor at Escola Brasileira de Administração Pública e de Empresas (EBAPE), Fundação Getúlio Vargas (FGV); Elaine S. T. Barbosa is now Executive Manager at Instituto de Desenvolvimento Educacional (IDE) at Fundação Getúlio Vargas (FGV); \& Estelle M. Morin is now Full professor at Management Department at HEC Montreal.

Correspondence concerning this article should be addressed to Lucia B. Oliveira, Rua Jornalista Orlando Dantas, 30, Botafogo, Rio de Janeiro, Rio de Janeiro, Brazil, CEP: 22231-010.

E-mail: lucia.oliveira@fgv.br

\section{EDITORIAL BOARD}

Editors-in-chief Janette Brunstein Silvio Popadiuk

Associated Editor Pedro Bendassoli

Technical Support Vitória Batista Santos Silva

\section{EDITORIAL PRODUCTION}

Publishing Coordination Irina Migliari

\section{Copyeditor}

Irina Migliari (English)

Carlos Villarruel (Portuguese)

\section{Language Editor}

Daniel de Almeida Leão (English)

Irina Migliari (Portuguese)
Layout Designer

Emap

Graphic Designer

Libro 